\title{
Modelling chlorophyll-a concentrations in a continental aquatic ecosystem of the Brazilian semi-arid region based on remote sensing ${ }^{1}$
}

\author{
Modelagem da concentração de clorofila-a em um ecossistema aquático continental \\ do seminário brasileiro baseada em sensoriamento remoto
}

\author{
Fernando Bezerra Lopes ${ }^{2 *}$, Cláudio Clemente Faria Barbosa ${ }^{3}$, Evlyn Marcia Leão de Moraes Novo ${ }^{3}$, Lino \\ Augusto Sander de Carvalho ${ }^{4}$, Eunice Maia de Andrade ${ }^{5}$ and Adunias dos Santos Teixeira ${ }^{2}$
}

\begin{abstract}
Remote-sensing data are essential to evaluate dynamic processes such as eutrophication and increases in the concentration of suspended sediments in continental aquatic systems. The aim of this study, therefore, was to develop models to estimate chlorophylla concentrations from remote-sensing data in continental waters of the Brazilian semi-arid region. The study area corresponds to the Orós reservoir, located in the state of Ceará. The models were developed based on measurements taken at 20 sampling points. Water samples were collected from the reservoir to i) analyse the chlorophyll-a, electrical conductivity, $\mathrm{pH}$ and turbidity; ii) take optical measurements in situ of water transparency and spectral radiance. Radiance measurements were carried out using an ASD FieldSpec ${ }^{\circledR 3}$ Hi-Res spectroradiometer. The spectral data were later transformed into reflectance values and used to test the performance of several models found in the literature for estimating chlorophyll-a. The results showed that for the three-band model, the maximum value for the coefficient of determination $\left(\mathrm{R}^{2}\right)$, of 0.88 , was obtained using the $\lambda_{1}=660 \mathrm{~nm}, \lambda_{2}=690 \mathrm{~nm}$ and $\lambda_{3}=717 \mathrm{~nm}$ spectral bands. The model employing two spectral bands presented the best performance $\left(\mathrm{R}^{2}=0.87\right)$ in the $\lambda_{1}=660 \mathrm{~nm}$ and $\lambda_{2}=690 \mathrm{~nm}$ bands. An absolute mean error of 5.35 and $5.00 \mu \mathrm{g} \mathrm{L}{ }^{-1}$ was found for the three- and two-band models respectively. The developed models are reliable, showing that chlorophyll-a concentrations can be quantified from remote-sensing field data with a high degree of accuracy.
\end{abstract}

Key words: Surface reservoirs. Models. Remote quantification. Eutrophication.

RESUMO - Os dados de sensoriamento remoto são essenciais para se avaliar processos de natureza dinâmica em sistemas aquáticos continentais, tais como a eutrofização e o aumento da concentração de sedimentos suspensos. Portanto, objetivou-se desenvolver modelos para estimar as concentrações de clorofila-a a partir de dados de sensoriamento remoto em águas continentais da região semiárida brasileira. A área de estudo corresponde ao reservatório Orós, localizado no estado do Ceará. O desenvolvimento dos modelos baseou-se em medidas realizadas em 20 pontos amostrais. Foram coletadas amostras de água no reservatório para a análise das seguintes variáveis: i) clorofila-a, condutividade elétrica, $\mathrm{pH}$, turbidez; ii) medições ópticas in situ da transparência da água e da radiância espectral. As medidas de radiância foram realizadas utilizando-se espectrorradiômetro ASD FieldSpec $\mathbb{R}$ Hi-Res. Posteriormente, os dados espectrais foram transformados em reflectância e utilizados para testar o desempenho de diversos modelos de estimativa de clorofila-a disponíveis na literatura. Os resultados indicaram que para o modelo de três bandas o valor máximo do coeficiente de determinação $\left(\mathrm{R}^{2}\right)$ de 0,88 foi obtido utilizando-se as bandas espectrais: $\lambda_{1}=660 \mathrm{~nm}, \lambda_{2}=690 \mathrm{~nm}$, e $\lambda_{3}=717 \mathrm{~nm}$. $O$ modelo de duas bandas espectrais apresentou melhor desempenho $\left(\mathrm{R}^{2}=0,87\right)$ para as bandas espectrais $\lambda_{1}=660 \mathrm{~nm}$ e $\lambda_{2}=690 \mathrm{~nm}$. Os modelos apresentaram um erro médio absoluto de 5,35 e 5,00 $\mu \mathrm{g} \mathrm{L}^{-1}$, respectivamente para os modelos de três e duas bandas espectrais. Os modelos desenvolvidos são confiáveis, indicando que esta variável limnológica pode ser quantificada a partir dos dados de sensoriamento remoto de campo com elevado grau de confiabilidade.

Palavras-chave: Reservatórios superficiais. Modelos. Quantificação remota. Eutrofização.

DOI: $10.5935 / 1806-6690.20210028$

Editor do artigo: Professor Alek Sandro Dutra - alekdutra@ufc.br

*Author for correspondence

Received for publication 01/03/2020; approved on 24/07/2020

${ }^{1}$ Parte da Tese de Doutorado do primeiro autor, apresentada ao Programa de Pós-Graduação em Engenharia Agrícola, Universidade Federal do Ceará 2Departamento de Engenharia Agrícola, Universidade Federal do Ceará/UFC, Av. Mister Hull, 2977, Campus do Pici, Bloco 804, Fortaleza-CE, Brasil, 60.450-760, lopesfb@ufc.br (ORCID ID 0000-0001-8285-2925), adunias@ufc.br (ORCID ID 0000-0002-1480-0944)

${ }^{3}$ Instituto Nacional de Pesquisas Espaciais/INPE, Av. dos Astronautas, 1758, - Jardim da Granja 12200243 - São José dos Campos-SP, Brasil, claudio.barbosa@inpe.br (ORCID ID 0000-0002-3221-9774), evlyn.novo@inpe.br (ORCID ID 0000-0002-1223-9276)

${ }^{4}$ Departamento de Meteorologia, Universidade Federal do Rio de Janeiro, 21941916 - Rio de Janeiro-RJ, Brasil, lino.sander@gmail.com (ORCID ID 0000-0001-8839-5366)

${ }^{5}$ Universidade Federal Rural do Semi-Árido/UFERSA, Mossoró-RN, Brasil, Bolsista PQ-1A, eandrade.ufc@gmail.com (ORCID ID 0000-0002-9750-0364) 


\section{INTRODUCTION}

Water is the most important substance in nature, as all known forms of life on the planet are dependent on it. As the global demand for water grows, the probability of supplying water of suitable quality decreases. In low-latitude arid and semi-arid regions, dams and the artificial perennialisation of rivers are the main sources of water for domestic, industrial and agricultural use (GUERREIRO et al., 2013).

Water has become increasingly more degraded over recent decades, precluding the use of important reservoirs (ANDRADE et al., 2020; CHAVES et al., 2019; LOPES et al., 2014a; ROCHA et al., 2016; SANTOS et al., 2014). Eutrophication is a major problem for water management around the world, and refers to the process by which aquatic environments are enriched with nutrients, mainly phosphorus and nitrogen, which are essential for the growth of phytoplankton (microalgae and cyanobacteria) and macrophytes (aquatic plants). According to Nyenje et al. (2010), 54\% of the lakes and reservoirs in Asia presented problems of eutrophication, $53 \%$ in Europe, $48 \%$ in North America, 28\% in Africa and 41\% in South America. In Brazil, according to data from the National Water Agency - ANA (2013), this fraction corresponded to 58\% of the lentic waterbodies. While according to data from the Water Resources Management Company of Ceará COGERH (2019), around $72 \%$ of the water in artificial surface reservoirs in the state was eutrophic.

For this reason, monitoring the water is essential for the sustainability and better management of water resources. The use of remote-sensing data can make this more successful, in addition to offering the possibility of monitoring on different spatial and temporal scales (LOPES et al., 2014b).

With remote sensing it is possible to evaluate responses that result from disturbances introduced by human activity, so as to predict the impact of these actions on sustainability in the medium and long term. These techniques can be used efficiently to prevent, verify and monitor changes in aquatic systems (BARBOSA et al., 2019).

The effects of optically active components (OAC) on the spectral reflectance of water have been widely discussed in the literature (BARBOSA; NOVO; MARTINS, 2019; CAIRO et al., 2020; CARVALHO et al., 2015; CARVALHO; BARBOSA; NOVO, 2013; CHEN et al., 2011; DALL'OLMO; GITELSON, 2005; GITELSON; SCHALLES; HLADIK, 2007; LE et al., 2013; LODHI et al., 1997; LOPES et al., 2016; MACIEL et al., 2019; NOVO et al., 2013). Given that these components influence remote-sensing reflectance (MOBLEY, 2004), which in turn is used to estimate the OAC concentration of aquatic systems, such measurements can be used to estimate the concentration of these components in the water column.

In this context, the use of remote sensing is seen as an important tool for monitoring continental aquatic systems and their watersheds, as it provides a synoptic view of the environment, identifying critical areas of pollution in the watershed and basin, and the areas of nutrient input in continental aquatic ecosystems (LOPES et al., 2016). As such, the aim of this study was to develop models to estimate chlorophyll-a concentrations in continental waters, using hyperspectral remote-sensing field data.

Figure 1 - Geographical location of the Orós reservoir, with the collection points for collecting water samples and in situ radiometric data

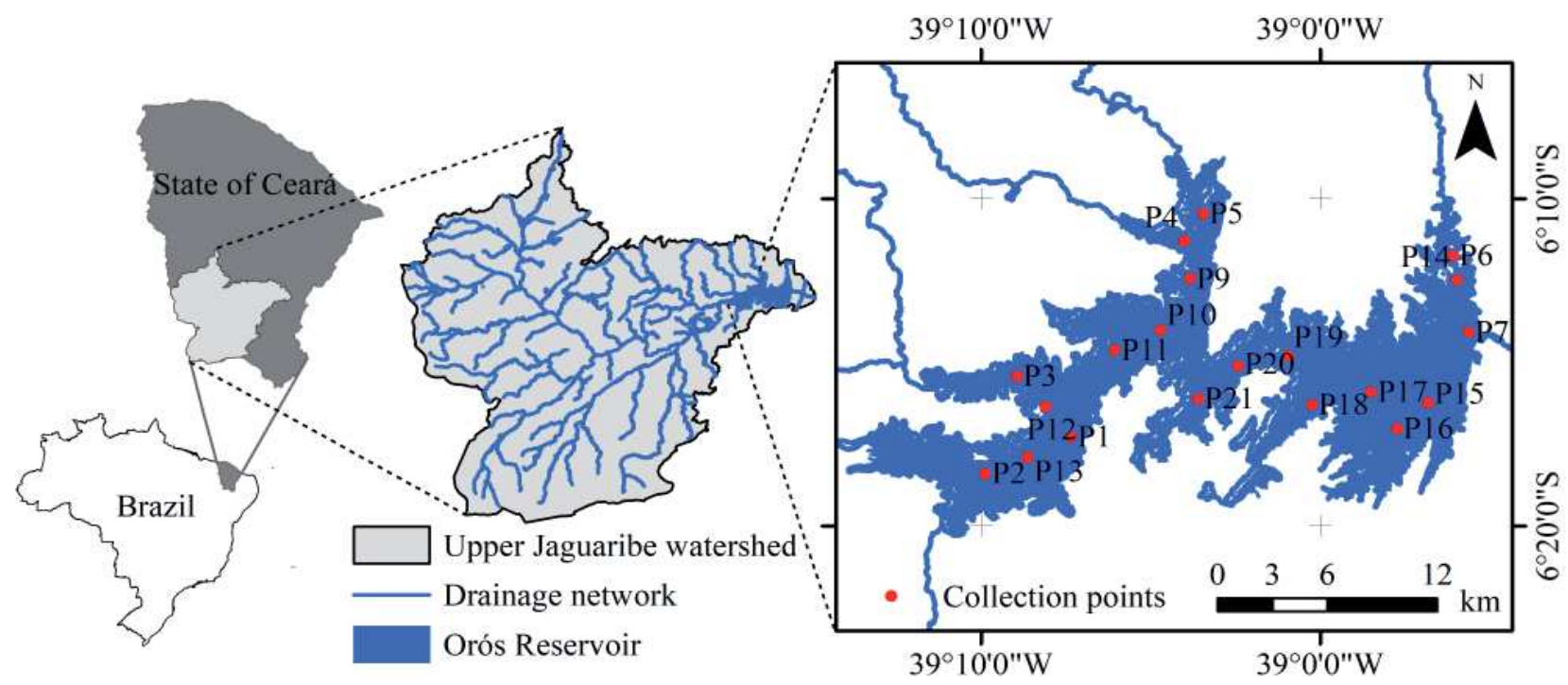




\section{MATERIAL AND METHODS}

The study area corresponds to the Orós reservoir (Figure 1), which has a full storage capacity of 1.94 billion $\mathrm{m}^{3}$ and a surface area of approximately $190 \mathrm{~km}^{2}$, and is the second largest reservoir in the state of Ceará. According to the Köppen classification, the region has a type BSw'h' climate, hot semi-arid, with maximum rainfall in the autumn, a mean monthly temperature always greater than $18^{\circ} \mathrm{C}$, and a mean annual rainfall (1974 to 2011) of $998 \pm 321 \mathrm{~mm}$.

Water samples were collected at a depth of $0.3 \mathrm{~m}$ from the surface, then packed in ice into Styrofoam containers, and sent to the laboratory for an analysis of the chlorophyll-a concentration, $\mathrm{pH}$, electrical conductivity (EC), and turbidity. Together with the water samples, in situ measurements were taken of water transparency, using a Secchi Disc, and of the spectral radiance of the aquatic system, using a spectroradiometer. Data were collected on 7 and 8 June 2011, and on 29 and 30 August 2011, at 20 points (Figure 1) distributed along the watershed starting at the main tributaries, the region of transition to the more lentic part of the reservoir.

Rainfall data were also used, including the daily rainfall $\left(\mathrm{mm} \mathrm{day}^{-1}\right)$, annual accumulated rainfall $\left(\mathrm{mm} \mathrm{yr}^{-1}\right)$ (WEATHER AND WATER RESOURCE FOUNDATION OF CEARÁ, 2019), and volume of water stored in the reservoir (\%) in 2011. The data on stored volume were obtained from the Hydrological Information Site of the State of Ceará (COGERH, 2019).

Spectral radiance was measured using the ASD FieldSpec ${ }^{\circledR} 3$ Hi-Res spectroradiometer with a $25^{\circ}$ field of view, a spectral resolution of $3 \mathrm{~nm}$ at $700 \mathrm{~nm}, 8.5 \mathrm{~nm}$ at $1400 \mathrm{~nm}$ and $6.5 \mathrm{~nm}$ at $2100 \mathrm{~nm}$, and covering the spectral range from 350 to $2500 \mathrm{~nm}$. A Spectralon reference plate was also used to represent a Lambertian surface. The measurements were taken between 10:00 and 14:00, the period of the lowest solar inclination, the greatest flow of radiant energy and suitable meteorological conditions, with little wind and a predominantly cloud-free sky.

Radiometric measurements were made following the methodology proposed by Milton (1987), i.e. preserving equal conditions of lighting and water surface as much as possible. The spectroradiometer was positioned at each sampling point at an inclination of $40^{\circ}$ relative to the vertical and an azimuth of $90^{\circ}$ in relation to the position of the Sun, minimising specular reflectance from the water. The height of the sensor in relation to the water surface was $1 \mathrm{~m}$.

For each point, 10 measurements of water radiance were taken, so that non-representative measurements could later be discarded, and the mean value for the remaining measurements calculated. The values for spectral radiance were converted into bidirectional reflectance using the expression:
$\mathrm{FRB}_{\lambda}=\mathrm{L}_{\mathrm{a}, \lambda} / \mathrm{L}_{\mathrm{r}, \lambda}$

where: $\mathrm{FRB}_{\lambda}=$ bidirectional reflectance factor (dimensionless); $\mathrm{L}_{\mathrm{a}, \lambda}=$ Spectral radiance of the target $\left(\mathrm{W} / \mathrm{cm}^{2} . \mathrm{sr} . \mu \mathrm{m}\right) ; \mathrm{L}_{\mathrm{r}, \lambda}=$ Spectral radiance of the reference plate $\left(\mathrm{W} / \mathrm{cm}^{2}\right.$.sr. $\left.\mu \mathrm{m}\right)$.

The models were developed using spectral field data from hyperspectral remote-sensing and the limnological data of the chlorophyll-a concentrations. Spectral regions having the highest correlation with the chlorophyll-a concentrations were selected to develop the regression models for estimating the amount of chlorophyll-a present in the waters of the Orós reservoir. The classical statistics, graphs and tables, and simple correlation were prepared using the Microsoft Office ${ }^{\circledR}$ Excel 365 spreadsheet software for the model based on the band ratio, and developed in this work using the ICE (Interactive Correlogram Environment) online tool from Ogashawara et al. (2014), which generates a two-dimensional correlogram between one dependent variable (Chl-a concentration) and various independent variables (Rrs). For the three-band model, routines from the MatLab ${ }^{\circledR}$ software were used to select the spectral bands with the highest correlation coefficient. The SPSS statistical software (Statistical Package for Social Sciences) v16.0 was then used to calculate the values for the coefficients (angular and linear) of the equation and the coefficients of determination $\left(\mathrm{r}^{2}\right)$.

Each combination of bands in the 400 to $900 \mathrm{~nm}$ spectral reflectance range of the FieldSpec ${ }^{\circledR} 3$ Hi-Res sensor was tested: both for simple models using only one spectral band, and for models using two or three spectral bands (CHEN et al., 2011; DALL'OLMO; GITELSON, 2005; GITELSON; SCHALLES; HLADIK, 2007; LE et al., 2013).

To evaluate the performance of the models statistically, statistical indicators were calculated by comparing the estimated values to the measurements not used in the regression analysis, i.e. during calibration (data from August 2011) and validation (data from June 2011). The statistical indicators used in this assessment were the correlation coefficient (r), coefficient of determination $\left(\mathrm{R}^{2}\right)$, F-test, Willmott index (d), Nash-Sutcliffe coefficient (NSE), absolute mean error (AME), and root mean square error (RMSE).

\section{RESULT AND DISCUSSION}

Two seasons can be seen, one rainy and the other dry (Figure 2A). Rainfall is concentrated in the first semester, mainly from February to May. The lowest values for monthly rainfall occur during the second semester. The total rainfall during 2011 was $1,651.5 \mathrm{~mm}$ (Figure 2A), 65.5\% higher than the historical average (1974 - 2011). The effect of this rainfall variability on the volume stored in the 
reservoir can be seen in Figure 2B. On 27 April 2011, the reservoir reached $100 \%$ of its water storage capacity when the accumulated total rainfall was $1,150.5 \mathrm{~mm}$, generating an accumulated runoff volume of $29.3 \%$ (Figure 2B). On 7 June 2011, when the accumulated total rainfall, due to a sequence of concentrated rainfall events during the first semester, was $1,484.50 \mathrm{~mm}$ (Figure 2A), the stored volume of water remained at $100 \%$ of capacity. By the next collection (29 August 2011), the accumulated volume was $97.70 \%$, i.e. there was a $2.30 \%$ reduction in the stored volume of water (Figure 2B). These results show that the stored volume does not depend only on total rainfall, but on the distribution of events over time and space.

A descriptive analysis and the spatial and temporal variability of the limnological variables are shown in Table 1. It can be seen that for June and August 2011 the hydrogen potential $(\mathrm{pH})$ showed a minimum value of 7.39 and 7.48, a mean of 7.73 and 7.66, and maximum of 8.19 and 7.85 respectively. According to CONAMA Resolution No. 357/2005, standard values for Class 2 Freshwater should be between 6.0 and 9.0 (BRAZIL, 2005). Similar results for the same reservoir were found by Ferreira et al. (2015), and Rocha et al. (2016). As it can be influenced by a large number of factors, $\mathrm{pH}$ is a complex limnological variable (ESTEVES, 2011; LOPES et al., 2008).
The predominant types of soil in the watershed of the Upper Jaguaribe are Neosols (31.90\%), Argisols (29.06\%), Luvisols (17.05\%) and Latosols (15.06\%). The watershed consists of $81.28 \%$ rocks of the Precambrian crystalline basement, represented by gneiss and various types of migmatite, quartzite and metalimestone associated with plutonic and metaplutonic rocks of predominantly granite composition, and of $18.72 \%$ sedimentary deposits comprising arenite, conglomerates, siltstone, shale, limestone, marl and gypsum (CEARÁ, 2009). Metalimestone releases carbonates, and contributes to the alkaline condition of the reservoir water (FERREIRA et al., 2015).

The $\mathrm{pH}$ of most natural waters is influenced by the concentration of $\mathrm{H}^{+}$ions originating from the ionisation of carbonic acid, which generates low $\mathrm{pH}$ values since it increases the hydrogen-ion concentration; carbonate and bicarbonate ions also react with the water, which raises $\mathrm{pH}$ values into the alkaline range by increasing the hydroxyl-ion concentration (ESTEVES, 2011). The high $\mathrm{pH}$ values in semi-arid reservoirs can be attributed to the geology, the soils, and to the activity of the phytoplankton (ROCHA et al., 2016).

Analysing the electrical conductivity (EC) of the water (Table 1) for use in irrigated agriculture, it can be seen that there is a low risk of the water in the Orós reservoir resulting in soil salinisation, EC $<700 \mu \mathrm{S} \mathrm{cm} \mathrm{cm}^{-1}$ (AYERS;

Figure 2 - Rainfall at the Iguatu weather station, located upstream of the reservoir (A), and volume of the Orós reservoir (B)
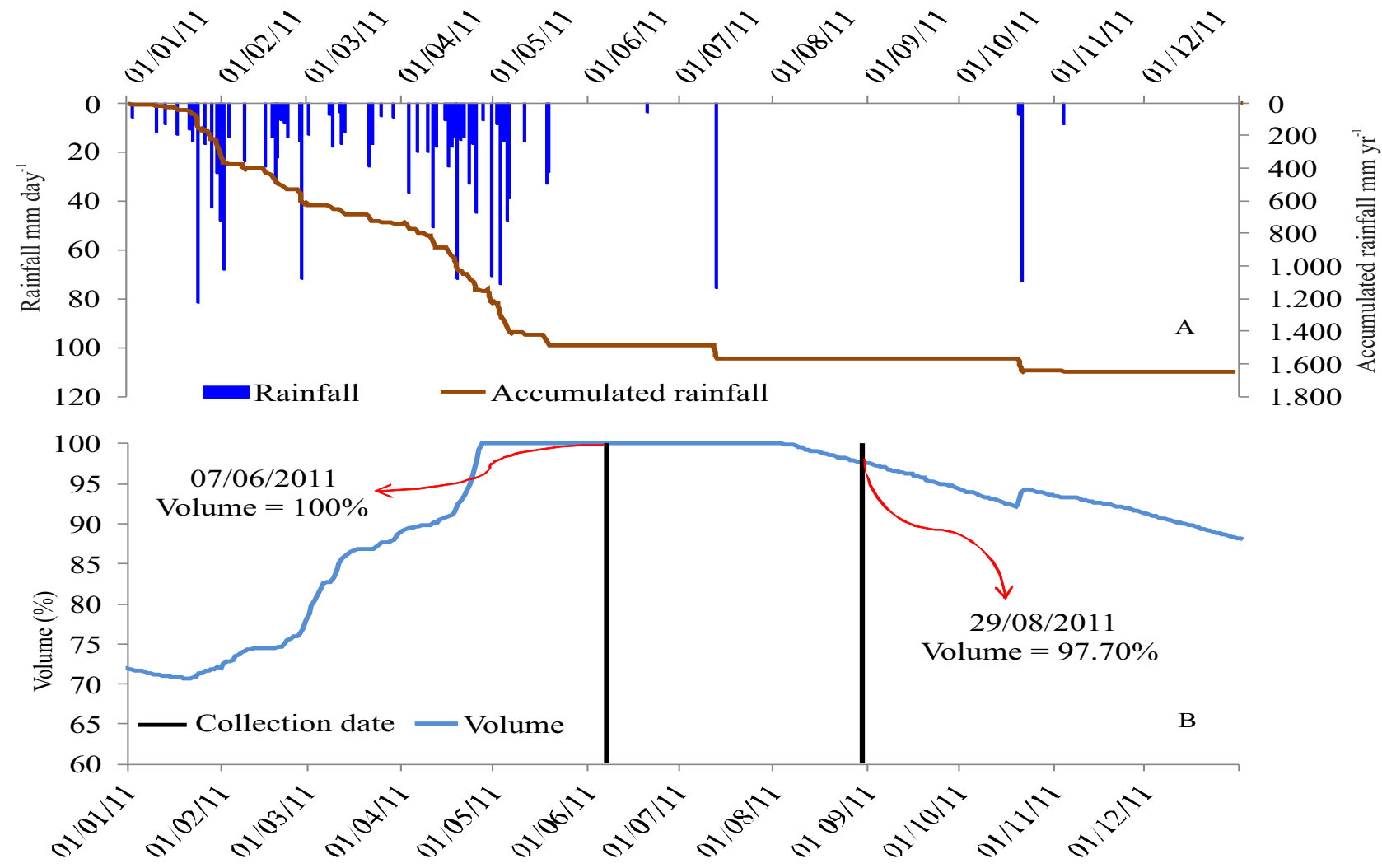
WESTCOT, 1999). The water in the Orós reservoir can be used on all types of soils and crops, with a low probability of problems with salinity. The EC had a minimum value of 230 to 200 , a mean of 270 to 230 , and a maximum of 310 to $250 \mu \mathrm{S} \mathrm{cm} \mathrm{cm}^{-1}$ respectively during June and August 2011. The higher values for salinity during the rainy season are due to entrainment of the salts, a result of the greater runoff (Figure 2). Similar results were found by Sales et al. (2014), studying water quality in the Orós reservoir for use in irrigation.

In the eutrophication process, the concentration of chlorophyll-a is considered a measure of the response of the waterbody to the presence of nutrients, especially total phosphorus and total nitrogen, and acts as an indicator of algae biomass. As such, the presence of nutrients and chlorophyll are satisfactory indicators of the cause and effect of the eutrophication process (LOPES et al., 2014a).

The chlorophyll-a concentration varied in space and time (Table 1), confirming the seasonal effects of the climate and the use and occupation of the land. The highest concentrations for the minimum, mean and maximum values of chlorophyll-a were recorded during the August 2011 campaign, the dry season. During this period, sediment input via drainage is very low, and turbidity is consequently reduced (Table 1), causing an increase in the euphotic zone due to the greater availability of light in the water column, which results in an increase in the development of algae and in photosynthetic activity. This effect of algal proliferation due to the increased energy available and constant nutrient input from point and diffuse sources, was also verified by Santos et al. (2014).

It appears that in $84 \%$ of the water samples analysed in this study, the chlorophyll-a concentration is classified as eutrophic, i.e. chlorophyll-a concentrations $\geq 12$ according to the limits defined by Salas and Martino (2001). Only 7.77\% of the permanent preservation area surrounding the Orós reservoir has natural vegetation; $42.38 \%$ of the area is occupied by natural pasture and has been improved through management techniques; $24.05 \%$ is occupied by secondary vegetation formed by sparse grasses and shrubs; $15.84 \%$ contains rice; $3.85 \%$ contains grasses, e.g. artificial pasture; $2.08 \%$ contains maize; and $4.03 \%$ has other crops and uses (SOARES et al., 2009). The eutrophic level of the samples is indicative of the inappropriate occupation, use and management of the land around the reservoir, in the basin and in the watershed (LOPES et al., 2014a; MAIA; LOPES; ANDRADE, 2018). Chlorophyll-a production is influenced by several factors including the supply of nutrients, especially total phosphorus and nitrogen, the temperature and water transparency (BATISTA et al., 2014).

Table 1 shows the minimum (2.00 and 2.60 NTU), mean ( 9.80 and $4.28 \mathrm{NTU}$ ), and maximum (32.00 and 6.00 NTU) values for turbidity for June and August respectively. The main causes of the increase in water turbidity are suspended solids, which can be of natural origin (particles of rock, sand and silt, in addition to algae and other minerals) or anthropogenic (domestic and industrial waste, micro-organisms and eroded sediments). Maia, Lopes and Andrade (2018), and Chaves et al. (2019), when determining classes of land use and occupation in the area of the drainage basin of the Orós reservoir, found that around $37.0 \%$ of the total area is anthropogenic (urban occupation, road system, deforested, bare soil and rainfed agricultural activity). Human activity, the lack of sanitation, farming, solid waste, industry, fish farming in nets in the watersheds of the reservoirs, and many other activities represent a risk to the quality of continental waters.

Turbidity reduces penetration of the water column by the energy incident on the surface of the water, hampering photosynthesis and reducing oxygen replacement. Inorganic

Table 1 - Spatial and temporal variability of the limnological variables of the Orós Reservoir

\begin{tabular}{lccccc}
\hline \multirow{2}{*}{ Point } & \multicolumn{5}{c}{ June 2011} \\
\cline { 2 - 5 } & $\mathrm{pH}$ & $\mathrm{EC}\left(\mu \mathrm{S} \mathrm{cm}^{-1}\right)$ & $\mathrm{Chl}-\mathrm{a}\left(\mu \mathrm{g} \mathrm{L}^{-1}\right)$ & Turbidity $(\mathrm{NTU})$ & Transparency $(\mathrm{m})$ \\
\hline P1 & 7.56 & 240.00 & 7.00 & 26.00 & 0.64 \\
P2 & 7.82 & 260.00 & 4.75 & 32.00 & 0.67 \\
P3 & 7.90 & 230.00 & 16.93 & 30.00 & 0.66 \\
P4 & 8.01 & 260.00 & 27.77 & 4.10 & 0.74 \\
P5 & 7.71 & 260.00 & 24.14 & 5.00 & 0.63 \\
P6 & 7.48 & 310.00 & 17.84 & 2.00 & 1.02 \\
P7 & 7.55 & 300.00 & 15.27 & 4.50 & 1.40 \\
P9 & 7.54 & 250.00 & 24.72 & 5.10 & 0.74 \\
P10 & 8.04 & 250.00 & 29.64 & 4.40 & 0.75 \\
\hline
\end{tabular}


Continuation table 1

\begin{tabular}{|c|c|c|c|c|c|}
\hline P11 & 8.12 & 240.00 & 33.05 & 6.00 & 0.75 \\
\hline $\mathrm{P} 12$ & 7.72 & 240.00 & 7.32 & 26.00 & 0.63 \\
\hline P13 & 7.69 & 240.00 & 3.58 & 28.00 & 0.74 \\
\hline P14 & 7.52 & 300.00 & 13.46 & 3.10 & 1.12 \\
\hline P15 & 7.45 & 300.00 & 8.28 & 2.60 & 1.44 \\
\hline P16 & 7.39 & 300.00 & 8.97 & 3.10 & 1.97 \\
\hline P17 & 7.54 & 290.00 & 18.10 & 2.80 & 1.18 \\
\hline P18 & 7.61 & 270.00 & 16.55 & 2.90 & 1.14 \\
\hline P19 & 7.59 & 270.00 & 17.57 & 2.50 & 0.98 \\
\hline P20 & 8.16 & 260.00 & 26.22 & 3.30 & 0.77 \\
\hline P21 & 8.19 & 250.00 & 31.51 & 2.60 & 0.73 \\
\hline Mean & 7.73 & 270.00 & 17.63 & 9.80 & 0.94 \\
\hline Standard Deviation & 0.25 & 20.00 & 8.98 & 10.85 & 0.34 \\
\hline Minimum & 7.39 & 230.00 & 3.58 & 2.00 & 0.63 \\
\hline \multirow[t]{2}{*}{ Maximum } & 8.19 & 310.00 & 33.05 & 32.00 & 1.97 \\
\hline & \multicolumn{5}{|c|}{ August 2011} \\
\hline $\mathrm{P} 3$ & 7.57 & 230.00 & 28.25 & 5.10 & 0.69 \\
\hline P4 & 7.62 & 200.00 & 41.28 & 4.70 & 0.55 \\
\hline P5 & 7.48 & 230.00 & 46.99 & 5.50 & 0.64 \\
\hline P6 & 7.52 & 250.00 & 18.80 & 4.40 & 1.40 \\
\hline P7 & 7.63 & 250.00 & 14.58 & 3.90 & 1.46 \\
\hline P9 & 7.85 & 230.00 & 34.71 & 3.90 & 0.68 \\
\hline $\mathrm{P} 10$ & 7.61 & 240.00 & 25.42 & 4.40 & 0.85 \\
\hline P11 & 7.59 & 230.00 & 27.23 & 4.20 & 0.83 \\
\hline $\mathrm{P} 12$ & 7.71 & 230.00 & 32.79 & 4.30 & 0.78 \\
\hline $\mathrm{P} 13$ & 7.73 & 230.00 & 25.31 & 6.00 & 1.40 \\
\hline P14 & 7.81 & 250.00 & 15.59 & 4.10 & 1.62 \\
\hline P15 & 7.67 & 230.00 & 18.85 & 3.50 & 1.65 \\
\hline P16 & 7.66 & 230.00 & 19.25 & 2.60 & 1.25 \\
\hline P17 & 7.75 & 230.00 & 19.65 & 4.40 & 1.25 \\
\hline P18 & 7.58 & 230.00 & 22.91 & 3.60 & 1.09 \\
\hline P19 & 7.74 & 240.00 & 12.02 & 4.40 & 1.09 \\
\hline P21 & 7.70 & 230.00 & 25.79 & 3.80 & 0.85 \\
\hline Mean & 7.66 & 230.00 & 25.26 & 4.28 & 1.06 \\
\hline Standard Deviation & 0.10 & 10.00 & 9.16 & 0.76 & 0.35 \\
\hline Minimum & 7.48 & 200.00 & 12.02 & 2.60 & 0.55 \\
\hline Maximum & 7.85 & 250.00 & 46.99 & 6.00 & 1.65 \\
\hline
\end{tabular}

particles cause the reservoirs to silt up, with a consequent lowering of the water storage capacity; precipitation of these particles can disturb the aquatic ecosystem. Sediments can carry pesticides, metals and other toxic elements, and their deposition at the bottom of rivers and reservoirs is harmful to aquatic species and the ecosystem. 
The highest values for turbidity (Table 1) were seen for sampling points located in the upper part of the Orós reservoir (P01, P02, P03; P12 and P13) in July 2011, corresponding to the end of the rainy season in the region (Figure 2). Points P01, P02 and P13 are located in the main tributary of the Orós reservoir, the River Jaguaribe, whereas points P03 and P12 are located in the River Faé. The impact of the rainfall (Figure 2) on unprotected soil (CHAVES et al., 2019; MAIA; LOPES; ANDRADE, 2018) triggers the erosion process and increases the concentration of sediments that are transported and drained into the reservoirs.

The points with the highest turbidity values correspond to the entrances of the principal tributaries of the Orós reservoir, where the main input of suspended sediments to the waterbody occurs; whereas the smallest values are located in the lower part of the reservoir, close to the spillway. This can be explained by the deposition process that takes place throughout the waterbody due to energy dissipation, reducing the sediment transport capacity and turbidity.

Data on water transparency for the period under study are shown in Table 1. In June and August, the minimum values were 0.55 and $0.63 \mathrm{~m}$ and the maximum values 1.65 and 1.97 $\mathrm{m}$ for points $\mathrm{P} 5$ and $\mathrm{P} 15$ respectively. For water transparency, a strong spatial variation was seen between the sampling points over time. The lowest values for transparency were found at points located in the upper part of the watershed, which correspond to the shallowest region and the main inflows of rivers and streams to the Reservoir (Figure 1).

The radiance emerging from a waterbody is shaped by the composition and concentration of the optically active components present in that waterbody. The spatiotemporal dynamics of the composition and concentration of water masses in the Orós reservoir, identified by an analysis of the limnological variables (Table 1), was reflected significantly in the shape and amplitude of the spectra, as can be seen in Figure 3, which shows the sets of spectra obtained during the field campaigns.

In terms of amplitude, the spectra at the sampling points located upstream of the Orós reservoir, especially points P01, P02, P03, P12 and P13 (Figure 3A), measured at the end of the rainy season (June), showed the greatest reflectance. Considering that the magnitude of the reflectance is a function of the backscatter coefficient, and that this, in turn, is highly correlated with the concentration of suspended solids, these points presented the highest turbidity values (Table 1), which explains the higher values for spectral reflectance (LODHI et al., 1997).

Observing points P01, P02, P03, P12 and P13 for the collection made in June (Figure 3A), a shift to greater wavelengths in the visible range can be seen in the reflectance peak as the concentration of suspended sediments in the water column increases (Table 1)
(LODHI et al., 1997). Analysis of these points identifies a gradual increase in the reflectance of the water from 400 $\mathrm{nm}$ to approximately $580 \mathrm{~nm}$. At this peak of maximum reflectance, around $580 \mathrm{~nm}$, the points under observation differed by a percent reflectance that ranged from 7.75 to 9.75 (Figure 3A). From $580 \mathrm{~nm}$, the level was maintained until close to $650 \mathrm{~nm}$, when the reflectance again decreased, preserving the difference between the points. The sharp reduction in reflectance between 700 and $720 \mathrm{~nm}$ occurred due to increased absorption by the water.

For the remaining points in Figure 3A, and for all the points in the August campaign (Figure 3B), features can be seen that are characteristic of the spectral behaviour of waters rich in Chlorophyll-a Table 1) (DALL'OLMO; GITELSON, 2005; LE et al., 2013). Low reflectance can be seen, especially from 400 to $500 \mathrm{~nm}$, due to absorption by these pigments and by organic substances dissolved in the water in this region (BARBOSA; NOVO; MARTINS, 2019; MOBLEY, 2004). There is absorption at $438 \mathrm{~nm}$ due to absorbance by the chlorophyll-a; maximum reflectance in the green region, around $550 \mathrm{~nm}$, due to less absorption by the pigments; a further classic absorption point in the red, around $680 \mathrm{~nm}$, associated with the second maximum absorption point of chlorophyll-a; and a reflectance peak around $700 \mathrm{~nm}$, attributed to both high scattering and minimal absorption by each of the optically active components (DALL'OLMO; GITELSON, 2005; LE et al., 2013).

From the correlogram showing the relationship between the bidirectional reflectance factor and the variable that expresses the chlorophyll-a concentration (Figure 4A), it is possible to identify the spectral positions with the greatest correlation between chlorophyll-a and spectral reflectance when the aim is to develop models based on only one spectral band. It can be seen that the correlation coefficient (r) varied from -0.77 at $546 \mathrm{~nm}$ to 0.38 at $720 \mathrm{~nm}$. Figure 4A, shows a higher inverse correlation in the visible region around $546 \mathrm{~nm}$. The development of models in this region (around $550 \mathrm{~nm}$ ) is not recommended due to high interference from the various optically active components. The correlation was also expected to be positive in the region around $550 \mathrm{~nm}$. This behaviour justifies the use of models with two or more spectral bands (Figures 4B and 3C).

For the two-band model, the strongest correlation was with wavelengths in the red region, showing a maximum positive correlation coefficient of (0.936) for the range between $690 \mathrm{~nm}$ and $660 \mathrm{~nm}$ (Figure 4B). In studies by Bernardo et al. (2016), a high positive correlation $(0.91)$ also seen in the red region.

For the model employing three spectral bands to estimate the chlorophyll-a concentration, the three bands with the highest correlation coefficient were selected, respecting the conditions for developing the three-band 
model (CHEN et al., 2011; DALL'OLMO; GITELSON, 2005; GITELSON; SCHALLES; HLADIK, 2007; LE et al., 2013). The first wavelength ( $\lambda 1)$ with maximum sensitivity to chlorophyll-a was located at $660 \mathrm{~nm}$. However, the Rrs region $\left(\lambda_{1}\right)$ is also affected by absorption from tripton $\left(\mathrm{a}_{\text {tripton }}\right)$, organic matter $\left(\mathrm{a}_{\mathrm{OM}}\right)$ and the water itself $\left(\mathrm{a}_{\text {water }}\right)$, and by the backscatter coefficient $\left(b_{b}\right)$. Therefore, with the aim of optimising the estimate for the chlorophyll-a concentration, a second region located at $690 \mathrm{~nm}\left(\lambda_{2}\right)$ was selected to minimise the effects of the absorption by tripton $\left(a_{\text {tripton }}\right)$ and the dissolved organic matter $\left(\mathrm{a}_{\mathrm{OM}}\right)$ (DALL'OLMO; GITELSON, 2005). However, to minimise the effect of the backscatter coefficient, it was necessary to select a third region $\left(\lambda_{3}\right)$. This region was located in the near infrared, close to $717 \mathrm{~nm}$ (Figure 4C).

The maximum coefficient of determination $\mathrm{R}^{2}=$ 0.88 was obtained with the three-band model, $\lambda_{1}=660 \mathrm{~nm}$, $\lambda_{2}=690 \mathrm{~nm}$ and $\lambda_{3}=717 \mathrm{~nm}$ (Figure 5A). It appears that the two-band model showed the best performance for the $\lambda_{1}=660 \mathrm{~nm}$ and $\lambda 2=690 \mathrm{~nm}$ bands (Figure 5B) with a

Figure 3 - Spectral reflectance of the aquatic system of the Orós reservoir, field campaign carried out in June (A) and August (B) 2011

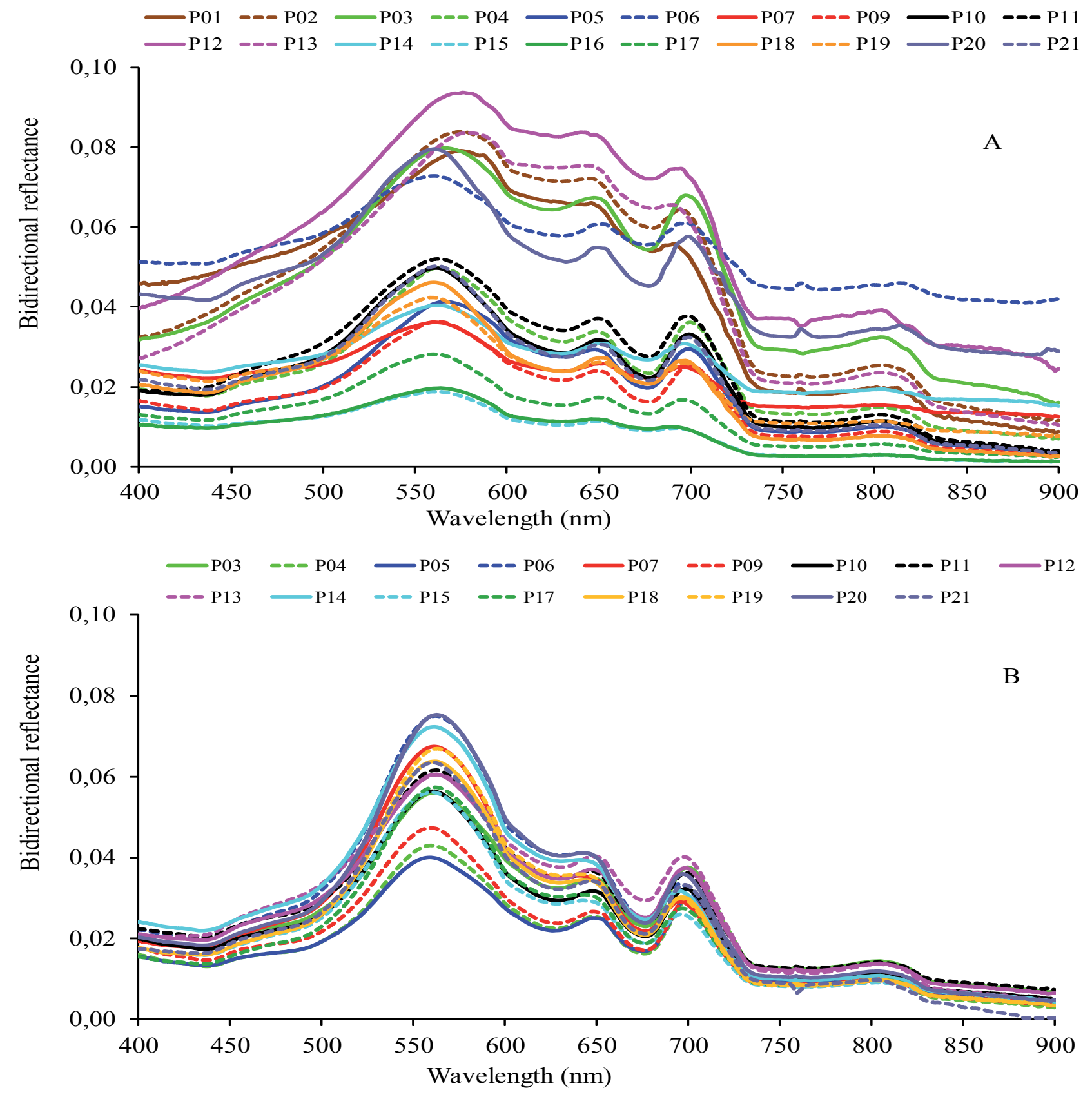


coefficient of determination of 0.876 . Both of the models for estimating the chlorophyll-a concentration were statistically significant at $1 \%$ (Figure 5). The models proved to be suitable for evaluating the spatial and temporal variability of the chlorophyll-a concentration throughout the waters of the Orós reservoir based on remote-sensing field data.

Figure 4 - Correlogram with the correlation coefficient (r) for the simple model with only one spectral band (A), for the twoband model (B), and for the model with three spectral bands (C)
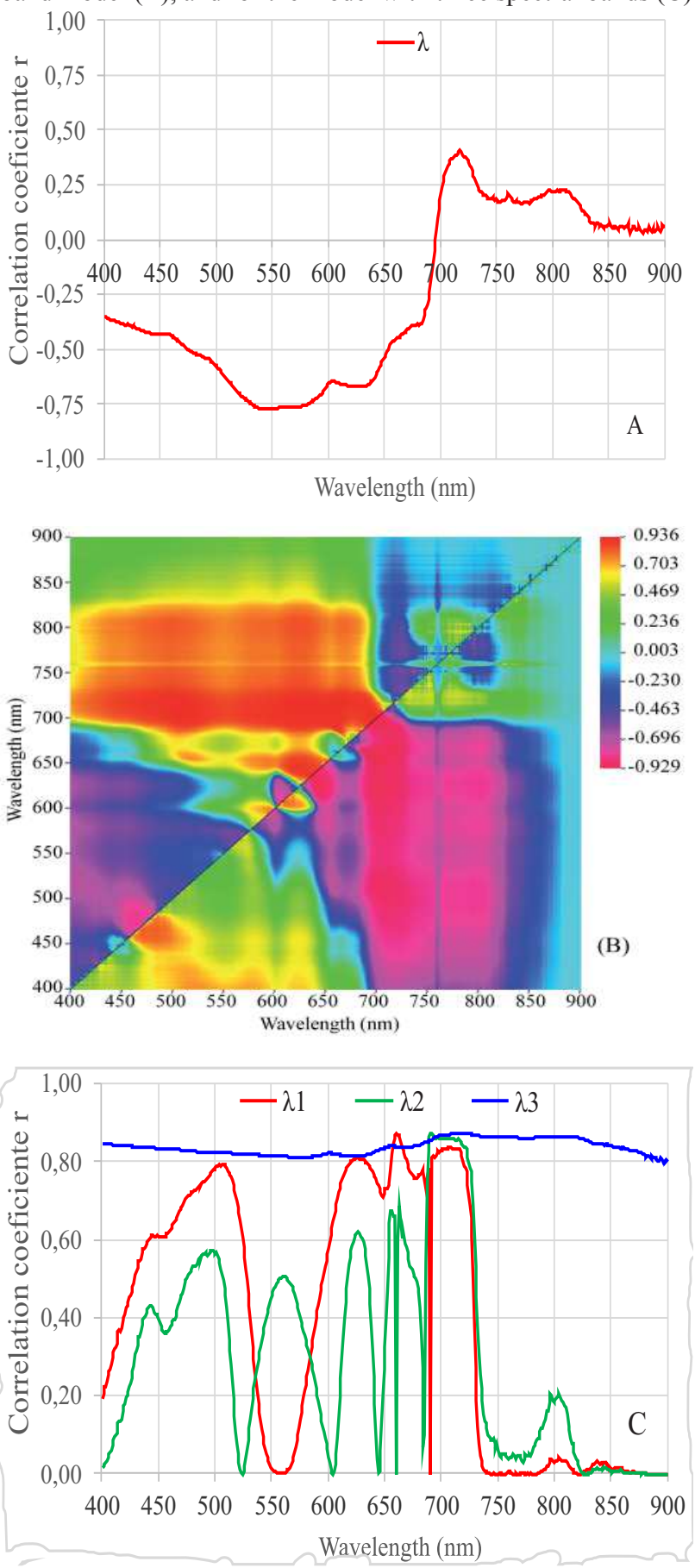

Applying the spectral bands of the three-band model developed by Gitelson, Schalles and Hladik (2007) for the waters of the Chesapeake Bay $\left(\lambda_{1}=675 \mathrm{~nm}, \lambda_{2}=695 \mathrm{~nm}\right.$, $\lambda_{3}=730 \mathrm{~nm}$ ) to the spectral measurements of August 2011 resulted in a lower coefficient of determination $\left(\mathrm{R}^{2}=0.77\right)$. Applying the bands $\left(\lambda_{1}=684 \mathrm{~nm}, \lambda_{2}=690 \mathrm{~nm}, \lambda_{3}=718 \mathrm{~nm}\right)$ of the model by Chen et al. (2011), calibrated for the River Pearl estuary in China, to the data from Orós, also resulted in poorer performance $\left(\mathrm{R}^{2}=0.76\right)$.

Results presented in the literature for the threeband model (Table 2) were found by other researchers. In general, for the period under study, the present research found values for the coefficient of determination $\left(\mathrm{R}^{2}\right)$ similar to those described in the literature (Figure 5).

However, it should be noted that the values for the band intervals found in the literature were applied to waters of temperate regions, with the exception of Carvalho, Barbosa and Novo (2013), who applied their values to lakes in the floodplain of Lago Grande do Curuai, in the state of

Figure 5 - Models for estimating chlorophyll-a concentrations in the Orós reservoir from reflectance field data from August 2011: (A) three and (B) two bands
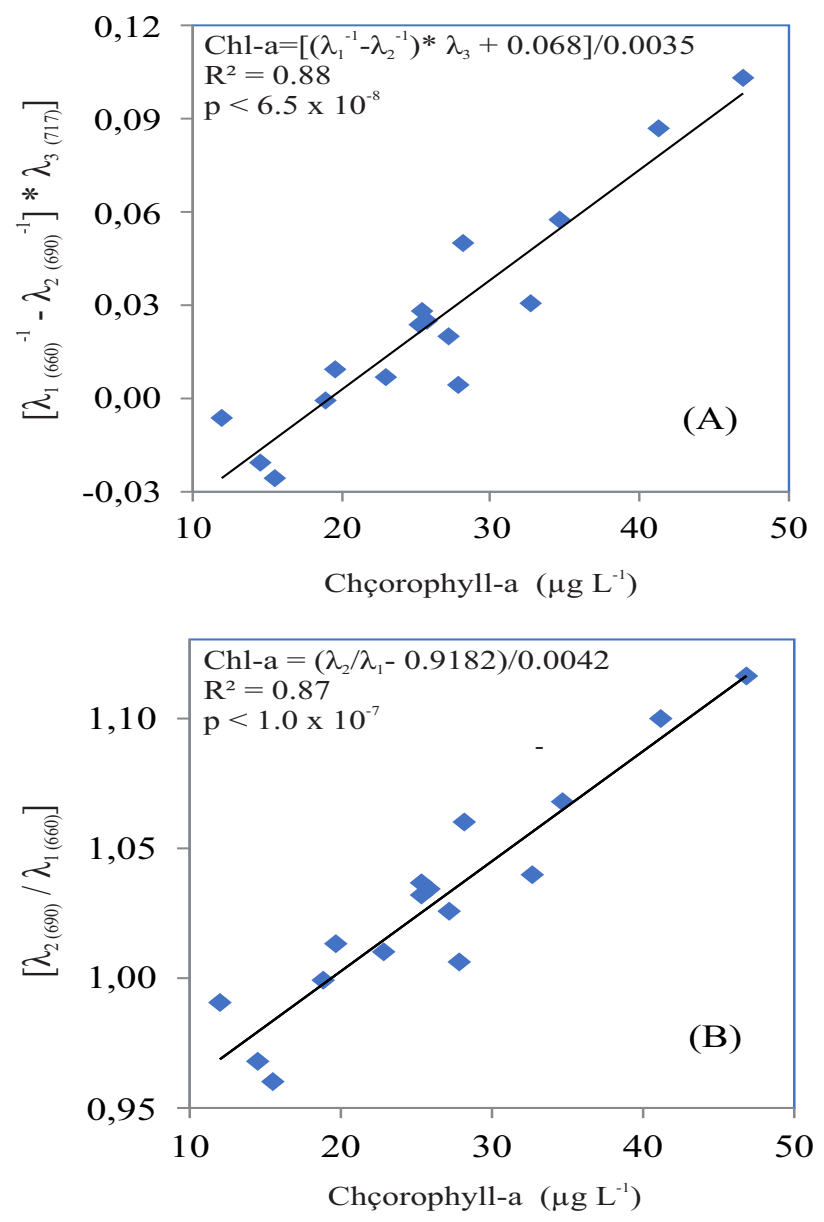
Pará. There is a certain similarity between intervals in the literature and those found in this work, especially the value for $\lambda_{2}$ in the model by Chen et al. (2011), which is equal to the value for the Orós reservoir, and the value for $\lambda_{3}$ by Chen et al. (2011), of $718 \mathrm{~nm}$, and for the Orós reservoir of $717 \mathrm{~nm}$. The values for $\lambda_{1}$ found in the literature (DALL'OLMO; GITELSON, 2005; GITELSON; SCHALLES; HLADIK, 2007) are also similar to that found in the present study.
To assess any trend in the estimation errors, the residuals of the models were studied in scatter plots between the in situ collection data of the chlorophyll-a concentrations (Figure 6).

There was no obvious pattern for a systematic rise in the residuals for an increase or decrease in the chlorophyll-a concentration, i.e. the errors are randomly distributed (Figure 6). Furthermore, it can be seen that the

Table 2 - Comparison Between Authors - Three-Band Model

\begin{tabular}{lcc}
\hline Author & Bands $(\mathrm{nm})$ & $\mathrm{R}^{2}$ \\
\hline Dall'Olmo; Gitelson (2005) & $\left(\lambda_{1}\right)=671 ;\left(\lambda_{2}\right)=710 ;\left(\lambda_{3}\right)=740$ & 0.94 \\
Carvalho et al. (2013) & $\left(\lambda_{1}\right)=702.5 ;\left(\lambda_{2}\right)=705.5 ;\left(\lambda_{3}\right)=750.1$ & 0.85 \\
Chen et al. (2011) & $\left(\lambda_{1}\right)=684 ;\left(\lambda_{2}\right)=690 ;\left(\lambda_{3}\right)=718$ & 0.81 \\
Gitelson et al. $(2007)$ & $\left(\lambda_{1}\right)=675 ;\left(\lambda_{2}\right)=695 ;\left(\lambda_{3}\right)=730$ & 0.81 \\
\hline
\end{tabular}

Figure 6 - Dispersion between the residuals and chlorophyll-a concentrations in the Orós reservoir for the reflectance field data from August 2011: (A) three and (B) two bands
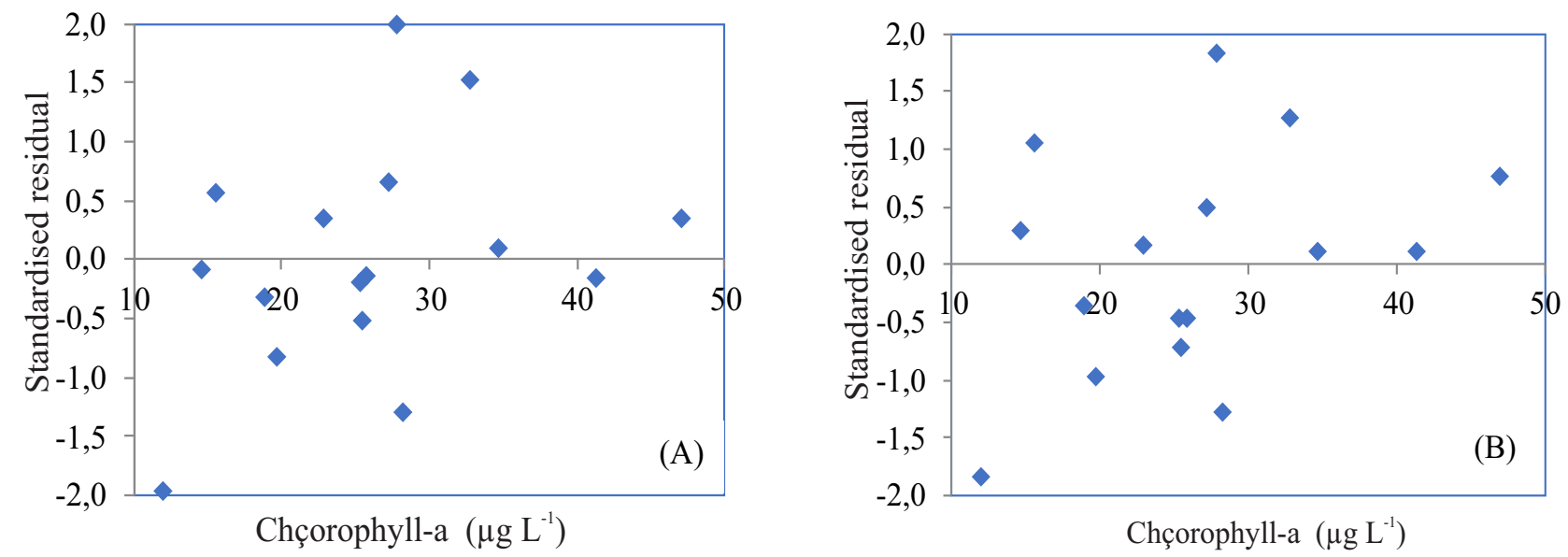

Figure 7 - Validation of the models for quantifying chlorophyll-a concentrations in the Orós reservoir using spectral field data from June 2011: (A) three and (B) two bands
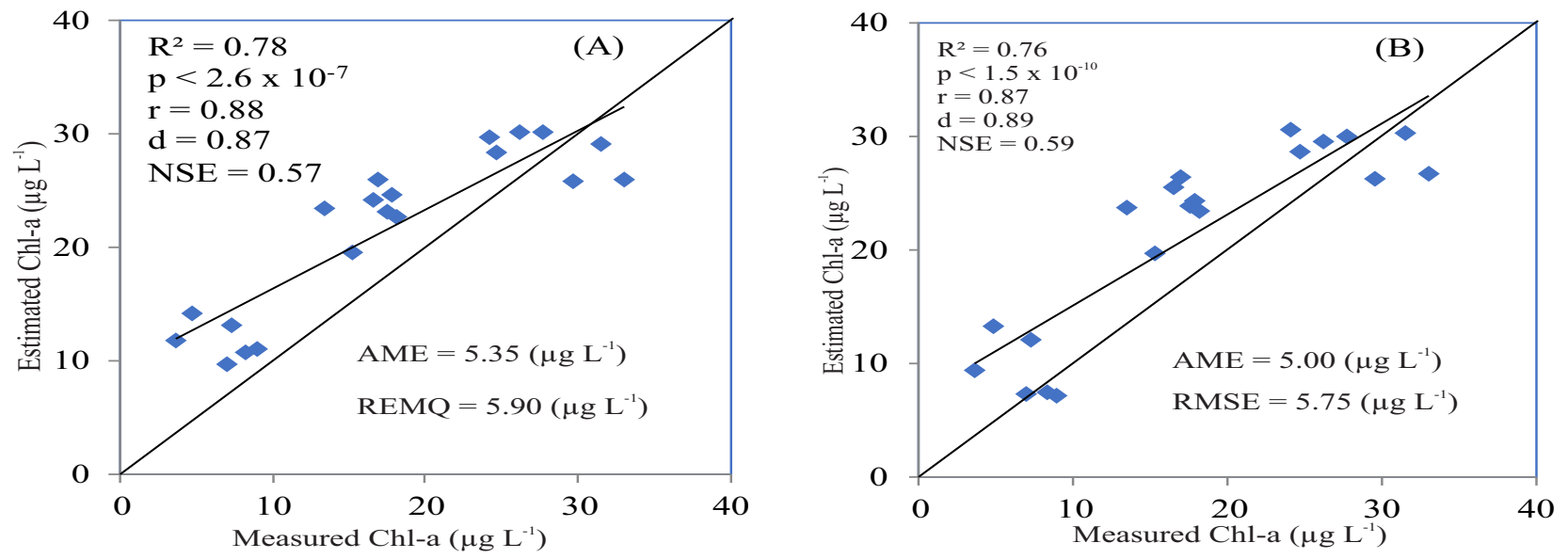
residuals are randomly distributed around zero, and that all the residual errors are between -2 and 2 .

According to the applied indices, the adjusted model has a correlation coefficient (r), Willmott index (d) and Nash-Sutcliffe coefficient (NSE) of $0.88,0.87$ and 0.57 respectively, for the three-band model (Figure 7A), and a value for $r$ of $0.87, d$ of 0.89 and NSE of 0.59 for the two-band model (Figure 7B).

For both models, the relationship between the measured and estimated data is statistically significant at $1 \%$. The models showed an absolute mean error (AME) of 5.35 and $5.00 \mu \mathrm{g} \mathrm{L}^{-1}$ for the three-band and two-band models respectively. The root mean square error (RMSE) was $5.90 \mu \mathrm{g} \mathrm{L}^{-1}$ for the three-band model and 5.75 for the two-band model (Figure 7).

\section{CONCLUSIONS}

1. It is possible to estimate chlorophyll-a concentrations, and evaluate and monitor water quality in continental aquatic systems of the semi-arid region using hyperspectral remote-sensing data;

2. The models developed for the limnological variable, chlorophyll-a, are reliable, allowing the chlorophyll-a to be accurately quantified using hyperspectral remotesensing data;

3. Both the two- and three-band models can be used to estimate the concentrations of chlorophyll-a in continental aquatic systems of the semi-arid region.

\section{ACKNOWLEDGEMENTS}

The authors would like to thank the Instituto Nacional de Ciência e Tecnologia em Salinidade-INCTSal. Thanks also go to the Coordenação de Aperfeiçoamento de Pessoal de Nível Superior (CAPES) for the scholarship granted to the lead author.

The authors wish to thank yet the Agência de Desenvolvimento do Estado do Ceará - ADECE (process no. 09/2017), and the Conselho Nacional de Desenvolvimento Científico e Tecnológico CNPq (process no 552490/2011-3) and (process no. 439.304/2018-0).

\section{REFERENCES}

ANDRADE, E. M. et al. Balance of nitrogen and phosphorus in a reservoir in the tropical semi-arid region. Revista Ciência Agronômica, v. 51, p. e20196800, 2020.
AYERS, R. S.; WESTCOT, D. W. A qualidade da água na agricultura. 2. ed. Campina Grande: UFPB, 1999. 153 p. (FAO, Irrigação e Drenagem, 29).

BARBOSA, C. C. F.; NOVO, E. M. L. M.; MARTINS, V. S. Introdução ao sensoriamento remoto de sistemas aquáticos: princípios e aplicações. São José dos Campos: Instituto Nacional de Pesquisas Espaciais, 2019. 161 p.

BATISTA, A. A. et al. Sazonalidade e variação espacial do índice de estado trófico do açude Orós, Ceará, Brasil. Revista Agro@ mbiente On-line, v. 8, p. 39, 2014.

BERNARDO, N. et al. Evaluation of the suitability of MODIS, OLCI and OLI for mapping the distribution of total suspended matter in the Barra Bonita Reservoir (Tietê River, Brazil). Remote Sensing Applications: Society and Environment, v. 4, p. 68-82, 2016.

BRASIL. Resolução $\mathrm{n}^{\circ}$ 357, de 17 de março de 2005. Dispõe sobre a classificação dos corpos de água e diretrizes ambientais para o seu enquadramento, bem como estabelece as condições e padrões de lançamento de efluentes, e dá outras providências. Diário Oficial da União, no 53, 18 mar. 2005. p. $58-63$

CAIRO, C. et al. Hybrid chlorophyll-a algorithm for assessing trophic states of a tropical brazilian reservoir based on MSI/ Sentinel-2 Data. Remote Sensing, v. 12, p. 40, 2020.

CARVALHO, L. A. S. et al. Implications of scatter corrections for absorption measurements on optical closure of Amazon floodplain lakes using the Spectral Absorption and Attenuation Meter (AC-S-WETLabs). Remote Sensing of Environment, v. 157, p. 123-137, 2015.

CARVAlHO, L. A. S.; BARBOSA, C. C. F.; NOVO, E. M. L. M. Ajuste de bandas de modelos empíricos de estimativa de clorofila aplicados à região da planície de inundação do Lago Grande Curuai - PA. In: SIMPÓSIO BRASILEIRO DE SENSORIAMENTO REMOTO, 16., 2013, Foz do Iguaçu. Anais [...]. São José dos campos: INPE, 2013. p. 89248931.

CEARÁ. Assembleia Legislativa. Conselho de Altos Estudos e Assuntos Estratégicos. Caderno regional da subbacia do Alto Jaguaribe. Fortaleza: INESP, 2009. 119 p.

CHAVES, L. C. G. et al. Water quality and anthropogenic impact in the watersheds of service reservoirs in the Brazilian semi-arid region. Revista Ciência Agronômica, v. 50, p. 223-233, 2019.

CHEN, S. et al. Evaluation of a three-band model for estimating chlorophyll-a concentration in tidal reaches of the Pearl River Estuary, China. Journal of Photogrammetry and Remote Sensing, v. 66, p. 356-364, 2011.

COMPANHIA DE GESTÃO DOS RECURSOS HÍDRICOS. Portal Hidrológico do Ceará. Fortaleza: COGERH, 2019. Disponível em: http://www.hidro.ce.gov.br/reservatorios/ volume. Acesso em: 5 dez. 2019.

DALL'OLMO, G.; GITELSON, A. A. Effect of bio-optical parameter variability on the remote estimation of chlorophyll-a concentration in turbid productive waters: experimental results. Applied Optics, v. 44, n. 3, p. 412-422, 2005. 
ESTEVES, F. Fundamentos de limnologia. 3. ed. Rio de Janeiro: Interciência, 2011. 826 p.

FERREIRA, K. C. D. et al. Adapting the National Sanitation Foundation water quality index to the Brazilian semiarid. Revista Ciência Agronômica, v. 46, p. 277-286, 2015.

FUNDAÇÃO CEARENSE DE METEOROLOGIA E RECURSOS HÍDRICOS. Redes de monitoramento. Fortaleza: FUNCEME, 2019. Disponível em: http://www.funceme.br. Acesso em: 25 fev. 2019.

GITElson, A. A.; SCHALleS J. F.; HLADIK.; C. M. Remote chlorophyll-a retrieval in turbid, productive estuaries: Chesapeake Bay case study. Remote Sensing of Environment, v. 109, n. 4, p. 464-472, 2007.

GUERREIRO, M. J. S. et al. Long-term variation of precipitation indices in Ceará State, Northeast Brazil. International Journal of Climatology, v. 33, p. 2929-2939, 2013.

LE, C. et al. Evaluation of chlorophyll-a remote sensing algorithms for an optically complex estuary. Remote Sensing of Environment, v. 129, p. 75-89, 2013.

LODHI, M. A. et al. The potential for remote sensing of loess soils suspended in surface waters. Journal of the American Water Resources Association, v. 33, n. 1, p. 111-117, 1997.

LOPES, F. B. et al. Assessment of the water quality in a large reservoir in semiarid region of Brazil. Revista Brasileira de Engenharia Agrícola e Ambiental, v. 18, p. 437-445, 2014a.

LOPES, F. B. et al. Mapa da qualidade das águas do rio Acaraú, pelo emprego do IQA e Geoprocessamento. Revista Ciência Agronômica, v. 39, p. 392-402, 2008.

LOPES, F. B. et al. Modelagem da qualidade das águas a partir de sensoriamento remoto hiperespectral. Revista Brasileira de Engenharia Agrícola e Ambiental, v. 18, p. 13-19, 2014b.

LOPES, F. B. et al. Simulation of spectral bands of the MERIS sensor to estimate chlorophyll-a concentrations in a reservoir of the semi-arid region. Agro@mbiente On-line, v. 10, p. 96-106, 2016.
MACIEL, D. et al. Retrieving Total and Inorganic Suspended Sediments in Amazon Floodplain Lakes: a multisensor approach. Remote Sensing, v. 11, p. 1744, 2019.

MAIA, A. R. S.; LOPES, F. B.; ANDRADE, E. M. Influence of climatic seasonality on a survey of land use and cover in the semiarid region. Journal of Agricultural Science, v. 10, p. 311, 2018.

MILTON, E. J. Principles of field spectroscopy. International Journal of Remote Sensing, v. 8, p. 1807-1827, 1987.

MOBLEY, C. D. Light and water: radiative transfer in natural waters. [S. 1.]: Academic Press, 2004. 593 p.

NOVO, E. M. L. de M. et al. Proposal for a remote sensing trophic state index based upon Thematic Mapper/Landsat images. Revista Ambiente \& Água, v. 8, p. 65-82, 2013.

NYENJE, P. M. et al. Eutrophication and nutrient release in urban areas of sub-Saharan Africa-A review. Science of the Total Environment, v. 408, n. 3, p. 447-455, 2010.

OGASHAWARA, I. et al. Interactive Correlation Environment (ICE): a statistical Web tool for data collineatiry analysis. Remote Sensing, v. 6, p. 3059-3074, 2014.

ROCHA, F. C. et al. Physical-chemical determinant properties of biological communities in continental semi-arid waters. Environmental Monitoring and Assessment, v. 188, p. 1-15, 2016.

SALAS, H.; MARTINO, P. Metodologias simplificadas para la evaluación de eutroficación em lagos cálidos tropicales. LIMA: Programa Regional CEPIS/HPE/IOPS, 2001. 52 p.

SALES, M. M. et al. Variabilidade espacial e temporal da qualidade das águas em reservatório da região semiárida para fins de irrigação. Revista Brasileira de Agricultura Irrigada, v. 8, p. 411-421, 2014.

SANTOS, J. C. N. et al. Land use and trophic state dynamics in a tropical semi-arid reservoir. Revista Ciência Agronômica, v. 45, p. 35-44, 2014.

SOARES, Z. M. L. et al. Uso e ocupação da terra nas áreas de entorno do açude Orós com vistas ao ordenamento territorial. In: SIMPÓSIO BRASILEIRO DE SENSORIAMENTO REMOTO, 14., 2009, Natal. Anais [...]. Natal: INPE, 2009. p. 4417-4424. 